\title{
Comparison of a 52-kDa Phosphoprotein from Synaptic Plasma Membranes Related to Long-Term Potentiation and the Major Coated Vesicle Phosphoprotein
}

\author{
Loes H. Schrama, Pierre N. E: de Graan, Henk Zwiers, and Willem Hendrik Gispen \\ Division of Molecular Neurobiology, Institute of Molecular Biology and Medical Biotechnology, \\ Rudolf Magnus Institute for Pharmacology, Utrecht, The Netherlands
}

\begin{abstract}
In the in vitro hippocampal slice preparation a short tetanus induces long-term potentiation (LTP) and an increase in the post hoc phosphorylation of a 52-kDa pro. tein in synaptosomal plasma membranes (SPM) prepared from these slices. This $52-\mathrm{kDa}$ SPM phosphoprotein closely resembles the predominant phosphoprotein in coated vesicles, pp50, with respect to the insensitivity of its phosphorylation to $\mathrm{Ca}^{2+} /$ calmodulin and cyclic AMP. This resemblance prompted us to compare in rat brain the $52-\mathrm{kDa}$ SPM protein with pp50 in isolated coated vesicles. Both proteins appear to be very similar on basis of the following criteria: (1) relative molecular weight on sodium dodecyl sul-
\end{abstract}

fate-polyacrylamide gel electrophoresis, (2) peptide mapping, (3) phospho-amino acid content, and (4) isoelectric point. Since coated vesicles are thought to be involved in receptor-mediated endocytosis and membrane recycling, our data suggest that LTP-correlated changes in $52-\mathrm{kDa}$ phosphorylation may reflect increased coated vesicle activity. Key Words: Long-term potentiation-Protein phosphorylation-Coated vesicles-Synaptosomal plasma membranes. Schrama L. H. et al. Comparison of a $52-\mathrm{kDa}$ phosphoprotein from synaptic plasma membranes related to long-term potentiation and the major coated vesicle phosphoprotein. J. Neurochem. 47, 1843-1848 (1986).
In the in vitro hippocampal slice preparation longterm potentiation (LTP) has been studied extensively in a number of monosynaptic subsystems (Andersen eî al., 1971, 1980). In correlative studies on LTP and protein phosphorylation we have used the perforant path-granule cell subsystem to elicit and monitor LTP (Bär et al., 1980a, 1982; Lopes da Silva et al., $1982 a, b)$. Tetanic stimulation of the perforant path increased the phosphorylation of a $52-\mathrm{kDa}$ protein band as measured in a crude synaptosomal plasma membrane (SPM) fraction using a post hoc endogenous phosphorylation assay (Bär et al., 1980a, 1982). The phosphorylation of this protein band was also found to be sensitive to the opioid peptide enkephalin (Bår et al.g.1980b). Initial biochemical characterization revealed that the phosphorylation of this $52-\mathrm{kDa}$ protein was $\mathrm{Ca}^{2+} /$ calmodulin- and cyclic nucleotideindependent (Bår et al., 1982).

Brain coated vesicles contain a number of phospho- proteins in the range of $50-55 \mathrm{kDa}$ (Pfeffer et al., 1983). The two highest molecular weight phosphoproteins, 54 and $56 \mathrm{kDa}$, have been identified as $\alpha$ and $\beta$ tubulin, whereas the major phosphorylated protein is a 52-kDa protein, called pp50 (Pauloin et al., 1984). The phosphorylation of the latter protein is catalyzed by a casein kinase II-like enzyme (Kadota et al., 1984; Usami et al., 1984) and is not sensitive to modulation by the second messengers cyclic AMP, cyclic GMP, and calcium, or to modulation by the calcium binding protein calmodulin (Pauloin et al., 1982; Moskowitz et al., 1983). In search for the identity of the $52-\mathrm{kDa}$ protein (De Graan et al., 1985) it was realized that the major phosphoprotein in brain coated vesicles, pp50, shares both molecular weight and phosphorylation characteristics with the $52 \cdot \mathrm{kDa}$ protein in SPM (Kadota et al., 1982; Pauloin et al., 1982; Usami et al., 1982, 1984; Pfeffer et al., 1983; Moskowitz et al., 1983). In this study we compare the rat brain coated
Received November 14, 1985; revised June 20, 1986; accepted June 20, 1986.

Address correspondence and reprint requests to Dr. L. H. Schrama at Division of Molecular Neurobiology, Institute of Mo. lecular Biology and Medical Biotechnology, University of Utrecht, Padualaan 8, 3584 CH Utrecht, The Netherlands.
Abbreviations used: IEF, isoelectric focussing; IEP, isoelectric point; LTP, long-term potentiation: SAP, Staphylococcus aureus protease V8; SDS-PAGE, sodium dodecyl sulfate-polyacrylamide gel electrophoresis; SPM, synaptosomal plasma membranes. 
vesicle phosphoprotein to the $52 \mathrm{kDa}$ SPM phosphoprotein with respect to molecular weight, isoelectric point (IEP), phospho-amino acid composition, and peptide map.

\section{MATERIALS AND METHODS}

\section{Preparation of a coated vesicle-enriched fraction}

Coated vesicles were isolated according to the method of Pearse and Robinson (1984) with minor modifications. Frozen $\left(-20^{\circ} \mathrm{C}\right)$ rat brains were thawed and homogenized in four volumes of isolation buffer (buffer A), consisting of 10 $\mathrm{m} M N$-2-hydroxyethylpiperazine- $N^{\prime}$-2-ethanesulfonic acid (HEPES)-NaOH, pH 7.2; $150 \mathrm{~m} M \mathrm{NaCl} ; 1 \mathrm{~m} M$ EGTA; 0.5 $\mathrm{mM} \mathrm{MgCl} ; 0.02 \%$ (wt/vol) $\mathrm{NaN}_{3}$; and $0.2 \mathrm{mM}$ phenylmethylsulfonyl fluoride. The homogenate was centrifuged at $20,000 \mathrm{~g}$ for $30 \mathrm{~min}$ in a Sorvall SS-34 rotor at $4^{\circ} \mathrm{C}$. To the resulting supernatant Triton X-100 was added to a final concentration of $1 \%(\mathrm{vol} / \mathrm{vol})$ and the fraction was incubated for 15-25 min at room temperature until the turbidity in the solution had resolved. The Triton $\mathrm{X}$-100-ireated supernatant was centrifuged at $100,000 \mathrm{~g}$ for $60 \mathrm{~min}$ at $4^{\circ} \mathrm{C}$ in a Beckman SW 27 rotor and the resulting pellet was dissolved in a minimal volume ( $1 \mathrm{ml}$ per five brains) of buffer A containing $1 \%(\mathrm{vol} / \mathrm{vol})$ Triton $\mathrm{X} \cdot 100$. The resuspended pellet was loaded onto a discontinuous sucrose gradient of $7.5 \mathrm{ml}$ each $5,10,15,20$, and $25 \%$ (wt/vol) sucrose dissolved in buffer $\mathrm{A}$. The gradient was centrifuged in a Beckman SW 27 rotor at $45,000 \mathrm{~g}$ for $60 \mathrm{~min}$ at $4^{\circ} \mathrm{C}$. The $15-25 \%$ sucrose layers were collected and diluted three times in buffer B ( 10 $\mathrm{m} M \mathrm{Na}$-acetate, $10 \mathrm{~m} M \mathrm{Mg}$-acetate, $0.1 \mathrm{mM} \mathrm{Ca}$-acetate, pH 6.5) and centrifuged in a Beckman SW 27 rotor at $100,000 \mathrm{~g}$ for $60 \mathrm{~min}$ at $4^{\circ} \mathrm{C}$. The pellet was resuspended in buffer $B$ to give a final concentration of $1 \mathrm{mg} / \mathrm{ml}$ protein. The yield of this coated vesicle-enriched fraction (15-25\% sucrose layers) was $125 \mu \mathrm{g}$ protein/brain.

\section{Preparation of SPM and a wesicle-enriched fraction}

SPM were isolated from fresh rat brain according to the method of Kristjansson et al. (1982). The final resulting SPM pellet was resuspended in buffer $B$ to a protein concentration of $1 \mathrm{mg} / \mathrm{ml}$. The $0.4 M$ vesicle-enriched layer of the sucrose gradient used to isolate SPM was also collected in buffer $B$ and resuspended at a protein concentration of 1 $\mathrm{mg} / \mathrm{ml}$.

\section{Protein phosphorylation assay}

Endogenous protein phosphorylation was assayed as described previousiy by Zwiers et al. (1976) and Kristjansson et al. (1982). In brief, the incubations were as follows: the protein fraction $(10 \mu \mathrm{g})$ was preincubated at $30^{\circ} \mathrm{C}$ for $5 \mathrm{~min}$ in buffer $\mathrm{B}$, then $2 \mu \mathrm{Ci}\left[\gamma^{32} \mathrm{P}\right] A$ TP (sp act $3,000 \mathrm{Ci} / \mathrm{mmol}$, New England Nuclear, Boston, MA, U.S.A.) and 7.5 $\mu M$ ATP were added to a final volume of $25 \mu \mathrm{l}$. The reaction was terminated by addition of $12.5 \mu \mathrm{l}$ of a denaturing solution (Zwiers et al., 1976).

\section{Isolation of the 52-kDa protein from coated vesicles and SPM}

Phosphorylated coated vesicles and SPM were separated on an $11 \%$ sodium dodecyl sulfate-polyacrylamide gel electrophoresis (SDS-PAGE) gel. After staining and destaining of the gel an autoradiogram was made and the $52-\mathrm{kDa}$ phosphoprotein was excised from the gel. The accuracy of the excision was verified by a second autoradiogram of the gel.
The gel pieces were soaked for $20 \mathrm{~min}$ in buffer $\mathrm{C}$ [ $25 \mathrm{mM}$ Tris, $192.5 \mathrm{~m} M$ glycine, $0.1 \%$ (wt/vol) SDS, $\mathrm{pH} 8.3$ ) to remove excess methanol and glycine. The proteins were collected from the gel in buffer $\mathrm{C}$ in an Isco sample concentrator (Model 1750, Lincoln, NE, U.S.A.) at $3 \mathrm{~W}$ constant power $(6 \mathrm{~mA})$ for $2.5 \mathrm{~h}$ in a total volume of $200 \mu \mathrm{l}$. The purity of the preparations was verified by rerunning $20 \mu$ l on SDS-PAGE, staining, destaining, and autoradiography, The remainder of the fractions was dialyzed overnight against double-distilled water. The dialyzed fractions were dried and dissolved in $6 \mathrm{M} \mathrm{HCl}, 1, \mu \mathrm{M}$ thioglycolic acid for phospho-amino acid analysis or in $125 \mathrm{mM}$ Tris $\mathrm{HCl}, \mathrm{pH}$ 7.4 for peptide mapping (see below).

\section{Phospho-amino acid analysis}

The purified fractions containing the isolated $52-\mathrm{kDa}$ phosphoprotein from coated vesicles and SPM were each split into equal amounts. To one half of each fraction (100 $\mu \mathrm{l}), 10 \mu \mathrm{g}$ of the phospho-amino acid standards phosphoty. rosine, phosphothreonine, and phosphoserine (Sigma, St. Louis, MO, U.S.A.) were added. The preparations with and without standard were sealed in a glass capillary and incubated for $3 \mathrm{~h}$ at $110^{\circ} \mathrm{C}$. The hydrolysates were dried under vacuum and redissolved in double-distilled water repeatedly, until the $\mathrm{pH}$ was neutral. The samples were applied to Whatman 540 paper (height $40 \mathrm{~cm}$, width $20 \mathrm{~cm}$ ) and run for $2.5 \mathrm{~h}$ at $3,000 \mathrm{~V}$ in $5 \%$ (vol/vol) acetic acid, $1 \mathrm{mM}$ EDTA, pH 3.5 with pyridine. The amino acid standards were visualized with ninhydrin and marked with ${ }^{32} P_{\cdots}$ containing ink before an autoradiogram was made.

\section{Peptide mapping}

The isolated 52-kDa phosphoprotein was incubated in $125 \mathrm{~m} M$ Tris-HCl with $50 \mathrm{ng}$ Staphylococcus aureus protease V8 (SAP, Miles Laboratories, Slough, U.K.) in a total volume of $25 \mu \mathrm{l}$ at $30^{\circ} \mathrm{C}$ for the times indicated. The reaction was stopped by addition of $12.5 \mu \mathrm{l}$ of denaturing solution (Zwiers et al., 1976) and boiling for $10 \mathrm{~min}$. The incubated samples were separated on a $15 \%$ polyacrylamide gel.

\section{Two-dimensional gel electrophoresis}

Isoelectric focussing (IEF) followed by SDS-PAGE was performed on a $\mathrm{pH}$ 3.5-10 IEF gel with phosphorylated coated vesicles and SPM according to the method of Zwiers et al. (1980). Nonequilibrium $\mathrm{pH}$ gradient gel electrophoresis was performed according to the method of O'Farrell et al. (1977), with $1 \mathrm{mM} \mathrm{H} \mathrm{H}_{2} \mathrm{SO}_{4}$ as anodic solution and $0.1 M$ $\mathrm{NaOH}$ as cathodic solution. The rest of the conditions were the same as those described for IEF-SDS-PAGE by Zwiers et al. (1980).

\section{Protein determination}

Protein content was determined by the method of Lowry et al. (1951) using bovine serum albumin as standard.

\section{RESULTS}

\section{Relative molecular weight on SDS-PAGE}

Freshly isolated SPM, vesicles, and coated vesicles were phosphorylated, separated on an $11 \%$ SDS-polyacrylamide gel, and submitted to autoradiography (Fig. 1). On the autoradiogram the $52-\mathrm{kDa}$ bands in SPM (lanes 1) and in the vesicle-enriched fraction (lanes 2) show as a minor phosphoband, whereas the major phosphoprotein in coated vesicles (lanes 3) 


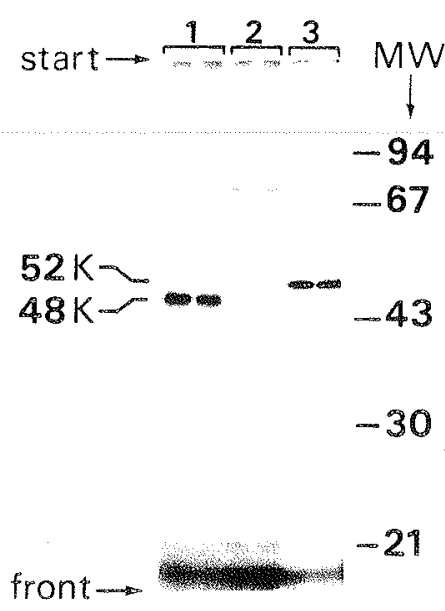

FG. 1. Molecular weight determination on SDS.PAGE. Ten micrograms of phosphorylated SPM (lanes 1), vesicles (lanes 2), and coated vesicles (lanes 3) were separated on an $11 \%$ SDS-polyacrylamide gel. The numbers to the right of the figure indicate the position of the low-molecular-weight markers from Pharmacia (Uppsala, Sweden). The arrow to the left of the figure indicates the position of the $52-\mathrm{kDa}$ phosphoprotein on the autoradiogram.

is visible as a predominant band that runs at the same height as the $52 \cdot \mathrm{kDa}$ phosphoproteins in lanes 1 and 2.

\section{Peptide mapping}

The $52-\mathrm{kDa}$ phosphoprotein was isolated from both SPM and coated vesicles after phosphorylation of $250 \mu \mathrm{g}$ of the respective fractions with $50 \mu \mathrm{Ci}[\gamma$ 。 ${ }^{32} \mathrm{PJATP}$ and $7.5 \mu M$ ATP for $30 \mathrm{~s}$. The amount of ${ }^{22} \mathrm{P}$ incorporation in both $52-\mathrm{kDa}$ proteins was deter. mined and an equal amount of radioactive $52-\mathrm{kDa}$ protein of the respective fractions was incubated in 25 $\mu 1$ with $50 \mathrm{ng} \mathrm{SAP}$ in $125 \mathrm{mM}$ Tris $\mathrm{HCl}$, pH 7.4, at $30^{\circ} \mathrm{C}$ for $1,2,5,10,20,40$, and $60 \mathrm{~min}$. The reaction was terminated with a denaturing solution $(10 \mathrm{~min}$, $100^{\circ} \mathrm{C}$ ). The resulting polypeptides were separated on a $15 \%$ polyacrylamide gel. The autoradiogram of the gel (Fig. 2) shows the digestion of the $52-\mathrm{kD}$ a protein after protease treatment of coated vesicles (left part of the figure) and SPM (right part of the figure). After 1 min of protease treatment only one digestion product $\left(\mathrm{M}_{\mathrm{r}} 43 \mathrm{kDa}\right.$, as judged from the molecular weight markers run alongside the gel) is visible in both prepa. rations. After a 20-40-min protease treatment the original 52-kDa phosphoprotein in both preparations was completely digested and two further breakdown products of 33 and $20 \mathrm{kDa}$ were formed.

Incubation of both $52-\mathrm{kDa}$ phosphoproteins with inactivated SAP $\left(10 \mathrm{~min}, 100^{\circ} \mathrm{C}\right)$ did not result in any breakdown of protein. Similar results with respect to time scale and digestion products were obtained when both $52 \cdot \mathrm{kDa}$ phosphoproteins were incubated with chymotrypsin A4 (Boehringer, Mannheim, F.R.G.; results not shown). Thus, the digestion of both 52 . $\mathrm{kDa}$ phosphoproteins with SAP resulted in identical

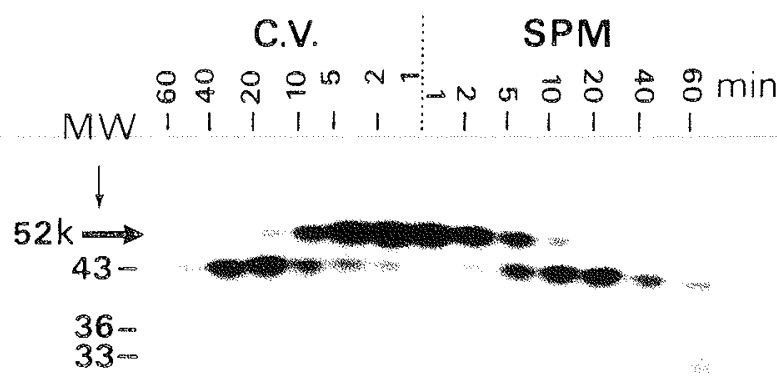

FIG. 2. Peptide mapping. Isolated phosphorylated 52-kDa protein from SPM and coated vesicles (C.V.) was incubated with 50 ng SAP for the times indicated at the top of the figure. The resulting polypeptides were separated on an $15 \%$ polyacrylamide gel. The numbers to the left of the figure indicate the relative molecular weights of the digestion products; the arrow points to the position of the original $52-\mathrm{kD}$ a phosphoprotein.

peptide maps. Moreover, the time scale of the formation of digestion products was very similar for both 52-kDa proteins.

\section{Phospho-amino acid analysis}

The 52-kDa phosphoproteins isolated from coated vesicles and SPM were hydrolyzed with $6 \mathrm{M} \mathrm{HCl}$ and separated by high-voltage paper electrophoresis. Both $52-\mathrm{kDa}$ proteins contained phosphoserine and phosphothreonine, whereas phosphotyrosine was absent (Fig. 3: coated vesicles, lane 1; SPM, lane 2). The phosphorylated products near the origin probably represent partially unhydrolyzed $52-\mathrm{kDa}$ phosphoprotein. The ratios of phosphothreonine to phosphoserine were 7:1 for the coated vesicle and 1:1 for the

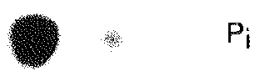

FIG. 3. Phospho-amino acid analysis. Isolated 52-kDa phosphoprotein from coated vesicles (lane 1) and SPM (lane 2) was hydrolyzed with 6 $\mathrm{M} \mathrm{HCl}$. The resulting products were separated by means of high-voltage paper electrophoresis. The position of reference nonradioactive phospho amino acids was marked with radioactive ink and is indicated to the right of the figure.
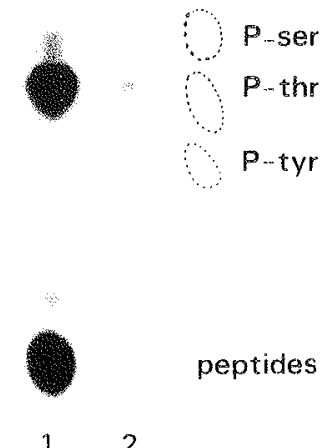
SPM $52-\mathrm{kDa}$ phosphoprotein as determined by liquid scintillation counting of the excised spots from the paper.

\section{Two-dimensional gel electrophoresis}

Coated vesicles and SPM were phosphorylated in the absence of calcium and in the presence of $1 \mathrm{mM}$ EGTA, to suppress the calcium-dependent phosphorylation of B-50 in SPM, the major phosphoprotein in this region of the gel (Zwiers et al., 1980, see Fig. 1, lanes 1). The proteins were separated on a $\mathrm{pH}$ 10-3.5 gradient in the first and on $11 \%$ SDS-PAGE in the second dimension. The resulting autoradiogram (Fig. 4) shows the $52-\mathrm{kDa}$ phosphoprotein in both coated vesicles (Fig. 4A) and SPM (Fig. 4B) as a homogeneous smear from the origin of the IEF gel $(\mathrm{pH} \mathrm{9.0)} \mathrm{to} \mathrm{the}$ middle (pH 6.5). The position of the 52-kDa phosphoprotein is indicated to the left of the figures by an arrow.

Comigration studies with a mixture of both phosphorylated fractions resulted in the same appearance of the $52-\mathrm{kDa}$ phosphoprotein on the autoradiogram, whereas no extra phosphoprotein spots were visible (results not shown). Separation of both phosphorylated fractions by nonequilibrium $\mathrm{pH}$ gradient gel electrophoresis according to O'Farrell et al. (1977) did not improve the resolution of the $52-\mathrm{kDa}$ phosphoprotein in the first dimension (results not shown). Isolated 52-kDa phosphoprotein from both sources was also run on both IEF and nonequilibrium $\mathrm{pH}$ gel electrophoresis. With this approach no improvement of resolution compared to the above described methods was achieved (data not shown).

\section{DISCUSSION}

LTP is a form of synaptic plasticity that is observed in many parts of the CNS when a short train of pulses at relative high frequency (a tetanus) is applied to a set of fibers (Schwartzkroin and Wester, 1975; Alger and Tyler, 1976; Andersen et al., 1980; Bliss and Dolphin, 1982). Tetanic stimulation of the perforant path of the hippocampal slice stimulated the phosphorylation of a $52-\mathrm{kDa}$ protein in a crude synaptosomal plasma membrane fraction (Bär et al., 1980a, 1982; Tielen et al., 1982). The degree of phosphorylation of this 52 . $\mathrm{kDa}$ protein was found to be highly correlated with the degree of LTP. Linear regression analysis of the degree of $52-\mathrm{kD}$ a phosphorylation versus the height of the postsynaptic potential showed a semilogarithmic plot with a correlation coefficient of $0.71(p<0.005$, Tielen et al., 1983).

In this article we present evidence that the L.TP.re. lated 52-kDa phosphoprotein in rat brain SPM is very similar to the $52-\mathrm{kDa}$ protein in isolated rat brain coated vesicles. This conclusion is based on the following observations: (1) the molecular weight of the $52-\mathrm{kDa}$ phosphoprotein in coated vesicles and SPM is identical when analyzed on an $11 \%$ polyacrylamide gel (Fig. 1); (2) digestion of isolated 52-kDa phosphoprotein from both sources with SAP (Fig. 2) or chy motrypsin $A 4$ resulted in the same breakdown products as analyzed by SDS-PAGE on an 15\% gel; (3) phospho-amino acid analysis revealed the same phosphorylated amino acids (i.e., threonine and serine) in both 52-kDa phosphoproteins (Fig. 3); (4) combined IEF with SDS-PAGE on an $11 \%$ gel indicated an identical behavior for both proteins, resulting in a smear between pH 9 and 6.5 (Fig. 4); (5) both phosphoproteins are phosphorylated by a $\mathrm{Ca}^{2+} /$ calmodulin- and cyclic nucleotide-independent protein kinase (Bảr et al., 1982).

The data on phospho-amino acid analysis of the 52 . $\mathrm{kDa}$ phosphoprotein in coated vesicles presented in this article show that the major phosphate acceptor amino acid is threonine. Direct comparison of these results with data from literature is difficult, since to the best of our knowledge no reports have been pre-

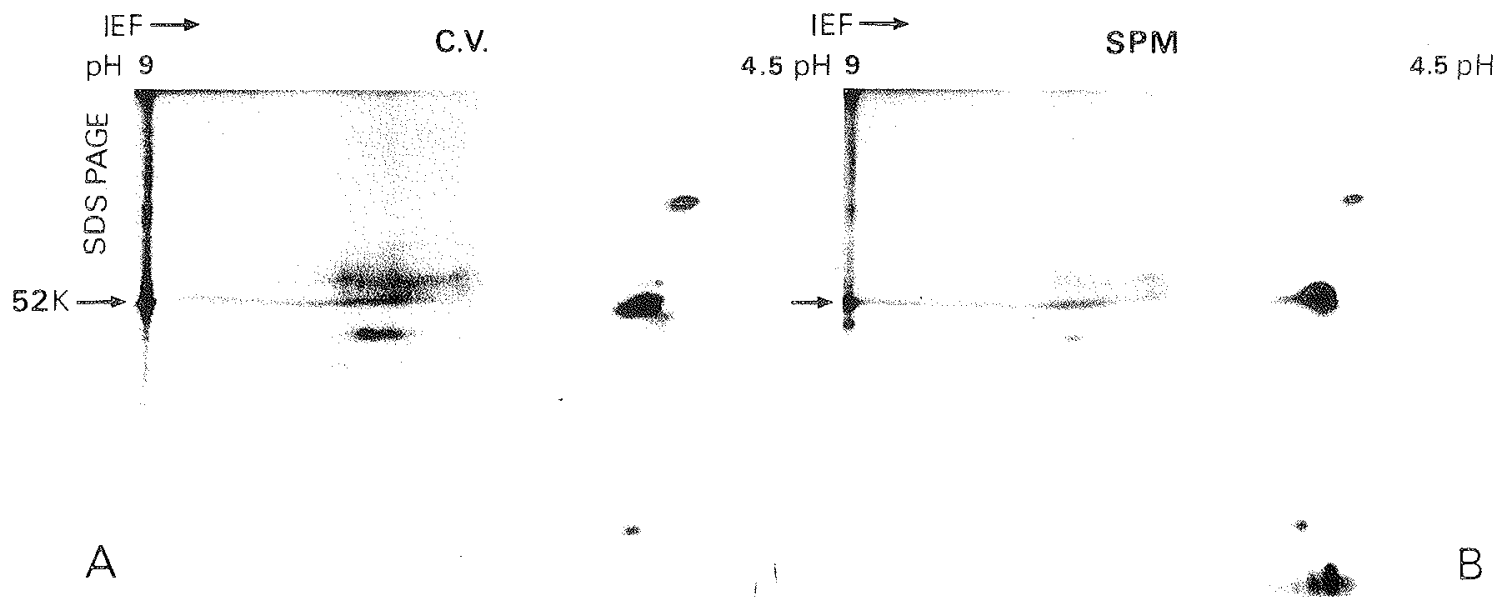

FIG.4. IEF and SDS-PAGE. Phosphorylated coated vesicles (C.V., A) and SPM (B) were separated on an pH $3.5-10$ isoelectric focussing gel followed by SDS-PAGE in the second dimension. The arrow indicates the position of the 52-kDa protein in both fractions. 
sented on phospho-amino acid analysis of a purified $52-\mathrm{kDa}$ preparation obtained from coated vesicles. Campbell and co-workers showed that in the coat fraction isolated from rat liver coated vesicles threonine was the major phosphate accepting amino acid, whereas serine was phosphorylated to a lesser extent (Campbell et al., 1984). Assuming that the 52-kDa protein was the major phosphoprotein in their coat fraction, their findings are in line with our results using isolated $52-\mathrm{kDa}$ protein from rat brain coated vesicles. In the $52-\mathrm{kDa}$ phosphoprotein isolated from. SPM less phosphate is incorporated into threonine than in serine. The qualitative differences in the labeling of serine and threonine between $52-\mathrm{kDa}$ protein from coated vesicles and from SPM are most likely due to differences in the initial phosphorylation state of the respective proteins, since the $52 \mathrm{kDa}$ protein containing fractions were not dephosphorylated before phosphorylation with $\left[\gamma_{-}{ }^{32} \mathrm{P}\right]$ ATP.

Campbell et al. (1984) also tried to determine the IEP of their $53 / 51-\mathrm{kDa}$ phosphoprotein(s) in coated vesicles from rat liver. The resolution they obtained on the IEF gel was as poor as that presented in this article and the IEP range was also $\mathrm{pH} 9-6.5$. The major phosphorylated coated vesicle protein from bovine brain and liver was also found to have an IEP ranging from pH 9 to 6.5 (Pfeffer et al., 1983). IEF of the purified $52-\mathrm{kDa}$ protein gave a similarly poor resolution.

Coated vesicles and coated pits have been impli. cated in a number of intracellular processes such as receptor-mediated endocytosis, secretory pathways, intracellular protein traffic, and presynaptic membrane recycling after transmitter release (Heuser and Reese, 1973; Goldstein et al., 1979; Kadota and Kadota, 1982). The precise role of the $52-\mathrm{kDa}$ protein and its phosphorylation in the function of coated vesicles is still unclear. Preliminary data may suggest that phosphorylation of the $52-\mathrm{kDa}$ protein promotes decoating of the coated vesicles (A. Pauloin, personal communication).

Previous results from our laboratory indicate that after application of a tetanus to a hippocampal slice the increase in $52-\mathrm{kDa}$ phosphorylation is positively correlated with the degree of potentiation (Tielen et al., 1983). During LTP there is an increase in neurotransmitter release (Dolphin et al., 1982), which will result in an increase in the amount of membrane ma. terial at the presynaptic membrane, Furthermore, chemical depolarization of synaptosomes from cerebral cortex results in the appearance of new large vesicles and coated vesicles (Fried and Blaustein, 1978) after prolonged stimulation. Electrical stimulation of the nerves of isolated frog sartonius muscles tran siently depleted synaptic vesicles (Heuser and Reese, 1973). The synaptic vesicle membrane was retrieved by coated vesicles and synaptic vesicles were recycled via intermediate cisternae (Heuser and Reese, 1973). The relative importance of coated vesicles in the process of membrane retrieval is still unclear, but the two examples presented above indicate a role for coated vesicles in membrane retrieval after increased neurotransmitter release. Thus we propose that the changes seen in $52-\mathrm{kDa}$ protein phosphorylation after LTP might reflect an increase in membrane retrieval concomitant with an increase in neurotransmitter release as a result of LTP.

Acknowledgment: J. van Binsbergen is gratefully acknowledged for his valuable technical assistance in the experiments presented in this paper. The authors further wish to thank Mr. J. H. Brakkee for his skillful biotechnical assistance and $\mathrm{Mr}$. $\mathrm{E}$. $\mathrm{D}$. Kluis for preparing and reproducing the figures. This work was supported by CLEO-grants A42 and $\mathrm{A} 47$.

\section{REFERENCES}

Alger B. E. and Tyler T. J. (1976) Long-term potentiation and shortterm plasticity in the CAl, CA3 and dentate regions of the hippocampal slice. Brain Res. 110, 463-480,

Andersen P., Bliss T. V. P., and Skrede K. K. (1971) Lamellar organization of hippocampal excitatory pathways. Exp. Brain Res. $13,222-238$

Andersen P., Sundberg S. H., Sveen O., Swann J. W., and Wigstrom H. (1980) Possible mechanisms for long-lasting potentiation of synaptic transmission in hippocampal slices from guinea pigs. J. Physiol. (Lond.) 302, 463-482.

Bär P. R., Schotman P., Gispen W. H., Tielen A. M., and Lopes da Silva F. H. (1980a) Changes in synaptic membrane phosphorylation after tetanic stimulation in the dentate area of the rat hippocampal slice. Brain Res. 198, 478-484.

Bär P. R., Schotman P., and Gispen W. H. (1980b) Enkephalins affect hippocampal membrane phosphorylation. Eur. J. Pharmacol. 65, 165-174.

Bär P. R., Tielen A. M., Lopes da Silva F. H., Zwiers H.o, and Gispen W. H. (1982) Membrane phosphoproteins of rat hippocampus: sensitivity to tetanic stimulation and enkephalin. Brain Res. $245,69-79$.

Bliss T. V. P. and Dolphin A. C. (1982) What is the mechanism of long-term potentiation in the hippocampus? Trends in $\mathrm{Neu}$ rosci. 5, 289-290.

Campbell C., Squicciarini J., Shia P. F., and Fine R. E. (1984) Identification of a protein kinase as an intrinsic component of rat liver coated vesicles. Biochemistry 23, 4420-4426.

De Graan P. N. E., Lopes da Silva F. H., and Gispen W. H. (1985) The role of hippocampal phosphoproteins in long-term potentiation, in The Hippocampus, Vol. 3 (Isaacson R. L. and Pribram K. H., eds), pp. 187-216. Plenum Press, New York

Dolphin A. C., Errington M. L., and Bliss T. V. P. (1982) Longterm potentiation of the perforant path in vivo is associated with increased glutamate release. Nature $297,496 \cdots 497$.

Fried R. C. and Blaustein M. P. (1978) Retrieval and recycling of synaptic vesicle membranes in pinched-off nerve terminals. $J$. Cell Biol. 78, 685 -700

Goldstein J. L., Anderson R. G. W., and Brown M. S. (1979) Coated pirs, coated vesicles and receptor mediated endocytosis. Nature $279,679-685$.

Heuser $\mathbf{J}$. and Reese T. (1973) Evidence for recycling of synaptic vesicle membrane during transmitter release at the frog neuromuscular junction. J. Cell Biol. 57, 315-344.

Kadota T. and Kadota K. (1982) Membrane retrieval by macropinocytosis in presynaptic terminals during transmitter release in cat synaptic ganglia in siru. J. Electron Microscop. 31, 73\% 80 .

Kadota K., Usami M., and Takahashi A. (1982) A protein kinase and its substrate associated with the outer coat and the inner core of coated vesicles from bovine brain. Biomed. Res. 3, 575578. 
Kadota K., Toyota N., Miyazaki N., and Kadota T. (1984) Casein kinase II activity in coated vesicles prepared from synaptosomes from bovine cerebral cortex, Biomed. Res, 5, 507-510.

Kristjansson $G, I$. , Zwiers $H$, Oestreicher A. B, and Gispen W. H. (1982) Evidence that the synaptic protein B-50 is localized ex. clusively in the nerve tissue. $J$. Neurochem. $39,37 \mathrm{l}-378$

Lopes da Silva F. H., Bär P. R., Tielen A. M, and Gispen W. H. (1982a) Plasticity in synaptic transmission and changes of membrane-bound protein phosphorylation. Prog. Brain Res. \$5, $369 \cdots 377$.

Lopes da Silva F. H., Bär P. R. Tielen A. M., and Gispen W. H. (1982b) Changes in membrane phosphorylation correlated with long-lasting potentiation in rat hippocampal slices. Prog. Brain Res. 56, 339-347.

Lowry O. H., Rosebrough N. J., Farr A. L., and Randall R. J. (1951) Protein measurement with the Folin phenol reagent. J. Biol. Chem. 193, 265-275.

Moskowitz N., Glassman A., Ores $C_{\text {. }}$, Schooh W., and Puszkin S. (1983) Phosphorylation of brain synaptic and coated vesicle proteins by endogenous $\mathrm{Ca}^{2+} /$ calmodulin- and cAMP-dependent protein kinases. J. Neurochem. 40, 711-718.

O'Farrell P. Z., Goodman H. M., and O'Farrell P. H. (1977) High resolution two-dimensional electrophoresis of basic as well as acidic proteins. Cell 12, 1133-1142.

Pauloin A., Bernier I., and Jollès P. (1982) Presence of cyclic nucleotide- $\mathrm{Ca}^{2+}$ independent protein kinase in bovine brain coated vesicles. Nature 298, 574-576.

Pauloin A., Loeb J., and Jollès P. (1984) Protein kinases(s) in bovine brain coated vesicles. Biochim. Biophys. Acta 799, 238-245.

Pearse B. M. F. and Robinson M. S. (1984) Purification and properties of $100 \mathrm{kD}$ proteins from coated vesicles and their reconstruction with clathrin. EMBO J.3, 1951-195\%.
Pfeffer S. R., Drubin D. G, and Kelly R. B. (1983) Identification of three coated vesicle components as $\alpha$ and $\beta$ tubulin linked to a phosphorylated 50,000.dalton polypeptide. J. Cell Biol. 97, $40-47$.

Schwartzkroin P. and Wester K. (1975) Long-lasting facilitation of a synaptic potential following tetanization in the in vitro hippocampal slice. Brain Res. 89, 107-119.

Tielen A. M., Lopes da Silva F. Ho, Bär P. R., and Gispen W. H. (1982) Long-lasting posttetanic potentiation in the dentate area of rat hippocampal slices and correlated changes in synaptic membrane phosphorylation, in Neuronal plasticity and Memory Formation (Ajmone Marsan C. and Matthies H., eds), pp. 239 -254. Raven Press, New York.

Tielen A. M., De Graan P. N. E, Mollevanger W. J., Lopes da Silva F. H., and Gispen W. H. (1983) Quantitative relationship between post-tetanic biochemical and electrophysiological changes in rat hippocampal slices. Brain Res. 277, 189 192.

Usami M., Takahashi A., and Kadota K. (1982) Biochemical characterization of coated vesicles from bovine brain. Neurochem. Res. 7, 882.

Usami M., Takahashi A., and Kadota K. (1984) Protein kinase and its endogenous substrates in coated vesicles, Biochim, Biophys. Acta 798, 306-312.

Zwiers H., Veldhuis D., Schotman P., and Gispen W. H. (1976) $\mathrm{ACTH}$, cyclic nucleotides, and protein phosphorylation in $v i$. tro. Neurochem. Res. 1, 669-677.

Zwiers H., Schotman P., and Gispen W. H. (1980) Purification and some characteristics of an ACTH-sensitive protein kinase and its substrate protein in rat brain membranes. $j$. Neurochem. 34, 1689-1699. 